\title{
Suicide attempts: epidemiologic trends towards geoprocessing
}

\author{
Tentativas de suicídio: tendências epidemiológicas \\ quanto ao geoprocessamento
}

\author{
Thassiany Sarmento Oliveira de Almeida ${ }^{1}$ \\ Sayonara Maria Lia Fook ${ }^{2}$ \\ Saulo Rios Mariz ${ }^{3}$ \\ Edwirde Luiz Silva Camêlo ${ }^{4}$ \\ Lidiane Cristina Félix Gomes ${ }^{5}$
}

\footnotetext{
${ }^{1}$ Universidade Estadual da Paraíba (UEPB). R. Baraúnas, Universitário. 58429-500 Campina Grande PB Brasil. thassysarmento@ hotmail.com

${ }^{2}$ Departamento de Farmácia, UEPB. Campina Grande PB Brasil.

${ }^{3}$ Universidade Federal de Campina Grande. Campina Grande PB Brasil. ${ }^{4}$ Departamento de Estatística, UEPB. Campina Grande PB Brasil.

${ }^{5}$ Universidade Federal do

Ceará. Fortaleza CE Brasil.
}

\begin{abstract}
In order to study data about suicide attempts and do the mapping of occurrence areas, it was developed an ecologic and exploring study, making use of techniques of geoprocessing, based on confirmed cases of suicide attempts. Cases of self-poisoning were included in the urban area of Campina Grande county, in the period of 20102013. A total of 446 suicide attempts were geo-referred, pointing up an incidence of 120 cases out of each 100,000 inhabitants. The sample was mostly feminine (66.4\%), and $62.3 \%$ being up to 30 years old. Kernel's map remarked hot spot areas. Compared to surrounding areas the suicide risk of populations within the hot spots was increased (38\%; Relative Risk $=1.38 ; p=0.0029)$, with an average estimative of 165 suicide attempts out of 100,000 inhabitants. Through identification of hot spots and index of living conditions of the neighborhoods, it is possible to set priorities in terms of public policies for the prevention of suicide attempts and control of the marketing of substances that are potentially toxic.
\end{abstract}

Key words Suicide attempted, Epidemiology, Toxicology, Spatial analysis
Resumo Para estudar os dados sobre tentativas de suicídio e mapear as áreas de incidência foi desenvolvido um estudo do tipo ecológico e exploratório, usando técnicas de geoprocessamento, com base em casos confirmados. Foram incluídos os casos de autoevenenamento, ocorridos na zona urbana do município de Campina Grande, para o periodo 2010-2013. Um total de 446 tentativas de suicídio foi georreferenciado, apontando uma incidência de 120 casos a cada 100.000 habitantes. A amostra foi majoritariamente feminina $(66,4 \%)$, com $62,3 \%$ possuindo até 30 anos de idade. $O$ mapa de Kernel evidenciou areas de hot spots. Populações dentro dos hot spots apresentaram um risco de suicídio 38\% maior (Risco Relativo= 1,38; $p=0,0029$ ), com uma estimativa média de 165 tentativas de suicídios por 100.000 habitantes. Através da identificação das áreas de hot spots $e$ do indice de condições de vida dos bairros, pode-se estabelecer as prioridades em termos de políticas públicas de prevenção das tentativas de suicídio e de controle da comercialização de substâncias com potencial tóxico.

Palavras-chave Tentativa de suicídio, Epidemiologia, Toxicologia, Análise espacial 


\section{Introdução}

According to data of United Nations (UN), suicide is found among the ten main causes of death in the world for individuals of all ages, thus being a relevant health care problem ${ }^{1}$. Studies made in several countries have shown that rates of suicide attempts are frequently high and provide evidence that this fact is continuously underestimated $^{2-4}$. The causes relate particularly to social factors like unemployment ${ }^{5}$ and illnesses as depression $^{6}$ and schizophrenia ${ }^{2-4}$.

Compared to European countries, Brazil presented, in the period between 1980 and 2000, low rates of suicide attempts (3.0 to 4.0 / 100,000 inhabitants $)^{7,8}$. However, in absolute numbers of suicide deaths, Brazil is among the 10 countries with highest number of death cases (about 6.0 death cases / 100.000 inhabitants per year) ${ }^{9}$.

The lethality of several suicide methods is an important determinant, which distinguishes suicide attempts ${ }^{10}$. Each time a risk factor for suicide attempt seriousness (previous attempts, masculine gender, elderliness, mental disorder presence, availability of highly lethal suicide methods) is added, the potential risk of suicide is done increaseing ${ }^{11}$.

Intoxication is a severe worldwide problem. According to the 32nd report of "National Poison Data System", a bio-surveillance tool that increases the capacity to identify threats of public health in the United States of America (USA), the number of human exposure to toxic substances was $2,165,142$, being intentional exposures represented $16.7 \%$ of the occurrences (suspects of suicide attempts) in $11.2 \%$ of the occurrences, the incorrect intentional use in $2.5 \%$, and intentional abuse in $2.2 \%)^{12}$. There are countless substances that may be used as a means for suicide attempts, like pesticides, raticide, abuse drugs, beyond foods and others. However, substances, medicaments, and pesticides were the most used all over the world ${ }^{12}$.

In Brazil 52,615 cases of attempts of suicide from voluntary intoxication ${ }^{13}$ were registered from 2010 to 2012 in the data bank of the Toxic Pharmacologic National Information System (Sinitox). According to data from SIH-SUS (Hospital Information System), of 112,295 hospital admissions, registered between 1998 and 2009, $70.7 \%$ occurred due to toxic substances, and the categories of substances causing intoxication were medications (46.2\%), followed by alcohol $(29.8 \%)$ and pesticides $(15.1 \%)^{14}$. From 2010 to 2015, the National System of Aggravations and
Notification (Sinan) registered 152,135 suicide attempts in the state of Paraíba, Northeast Brazil. Of these suicide attempts $39.5 \%$ occurred in the community of Campina Grande ${ }^{15}$.

The aim of the present study was to analyze suicide attempts through an ecological study in the county of Campina Grande, Paraiba and to map the incidence areas by using geoprocessing techniques.

\section{Material and methods}

\section{Drawing and study}

This is an ecologic and exploratory kind of study, in which space analysis techniques were used for area data, based on confirmed cases of suicide attempts.

\section{Study area}

The municipal district of Campina Grande is located approximately 512 meters above sea level in the countryside of the state of Paraiba - Brazil - ('Latitude -7.23072, longitude: - 35.8817, $7^{\circ} 13^{\prime}$ $51^{\prime \prime}$ South, $35^{\circ} 52^{\prime}$ 54" West). Municipal territory occupies an area of $594.182 \mathrm{~km}^{2}$, and has a population of 385.213 inhabitants (demographic density of 648.31 inhabitant per square kilometer), that are distributed in about 50 neighbourhoods and 6 districts ${ }^{16}$.

\section{Inclusion and exclusion criteria}

We included in this study cases of suicide attempts that occurred from 2010 to 2013 in the urban area of Campina Grande County, and were notified in the Toxicological Assistance and Information Centre in Campina Grande (CEATOX- CG). The cases registered in the rural area or in other counties of Paraiba state were not presented in the digital loop of the county. Thus, they were excluded from the research, as well as those whose addresses were not geo-referred.

\section{Population and sample}

In the present study 446 suicide cases were selected. The addresses registered in the SINAN's records were identified on the website of the post office and edited afterwards to provide them for geo-processing. 


\section{Variables}

The research was developed based on cases of self-poisoning by pesticides, remedies and household cleaning substances. Those were the most frequently notified agents by Ceatox in Campina Grande. In each case, the address of the suicide attempt was taken as an indication of exposure autochthony. Incidence rate of cases was determined as ratio between the number of notified cases and population estimates for the analysis unit. The urban area population used in the denominator for the incidence rate calculus was obtained from the population census in 2010, added to the annual index of population increase in the county, standing for $1.15 \%$ for the subsequent years.

\section{Spatial analysis}

The methodological sequence required that first, the instrument Google Fusion Tables were used to make the geo-coding. After that, Google Earth software was employed to manual tracking of the cases. In the Trackmaker software, afterwards, the conversion of data was done form $\mathrm{Kml}$ to Shp format, in order to manipulate them sequentially in the ArcGIS 10, Esri software. For the spatial statistic analysis, the ArcGIS 10 Esri was used. Statistic program 3.1.1 for Windows R version was used for Pearson's Chi squared test. Thematic maps were built for the analyzed time period, in order to visualize incident areas. Two maps were generated: the first one with highest Kernel density, consisting of areas with highest concentration of occurrence in the national territory, and the second one with spatial distribution of cases, based on Life Condition Index (LCI), an adapted version of the methodology elaborated by Paim et al. ${ }^{17}$. LCI made use of relative indicators to the life condition features. For each neighborhood area, seven indicators were calculated, such as: 1. Proportion of addresses (permanent private) having proper water supply (with inside piping from general service or private sources) (DAAA); 2. Proportion of addresses with adequate sewage installation (from general service or sceptic tank) (DISA); 3. Proportion of addresses having direct trash collecting (DCLA); 4. Proportion of population being from 10 to 14 years old, illiterate (PAn); 5. Proportion of breadwinners with income lower than or equal to two minimum wages (CDRM); 6. Proportion of illiterate breadwinners (CDAn); and 7. Average number of residents per address (DID) ${ }^{18}$. In a sequence, each neighborhood received a relative score to the ob- tained numbers, thus obtaining the sum of this score of the five indicators of each neighborhood, having as result the LCI.

The order of the scores allowed each neighborhood to be grouped in four extracts (quartis) made up of partially homogenous areas of lifing conditions according the to final score: better, regular, bad, and terrible. The LCI was distributed spatially in the thematic map by use of the ArcGIS software.

\section{Ethic aspects}

The project has been approved by the Ethic and Research Committee of the Paraiba State University (UEPB) respecting the 466/2012 CNS/ MS Resolution.

\section{Results}

An overall of 446 suicide attempts were geo-referred, pointing out to an incidence of 120 occurrences per 100,000 inhabitants. Of all suicide attempts $296(66.4 \%)$ and 150 (33,6\%) were undertaken by women and men, respectively. Of all suicide attempts 278 (62.3\%) were undertaken by individual's $\leq 30$ old. In all age groups, the number of individuals of female gender was superior to male gender, with exception of those ones $>60$ years old. We checked association between and aged: aged marked for over 60 and male gender, as well as between female gender and patients 20 years old or under that. The remarked categories were meaningfully different among them (P-value $=0,0027)$ : Remedies, in an isolated use, stand for $62.1 \%$ of all suicide attempts, and whenever associated with other chemical agents - as pesticides and beverages added up to $78.1 \%$.

Intoxication by intake of alcoholic drinks was 3.3 times more common among men compared to women. The Benzodiazepines, Diazepam and Clonazepam used in 109 (24,2\%) cases corresponded to the most used drugs. Diazepam was used solely or combined with other substances in $29(6.5 \%)$ and $24(5.4 \%)$ cases, respectively. Clonazepam was used solely or in combination with other substances in 23 (5.1\%) and 33 (7.4\%), respectively. According to Chart 1, there was an association between gender and type of toxic agent used (Pearson test was equal to 7,2035 $\mathrm{x} 10-5=0,000)$ :Attempts of suicide by application of remedies was more prominent among male, in contrast to women who applied more often pesticides of domestic use. 


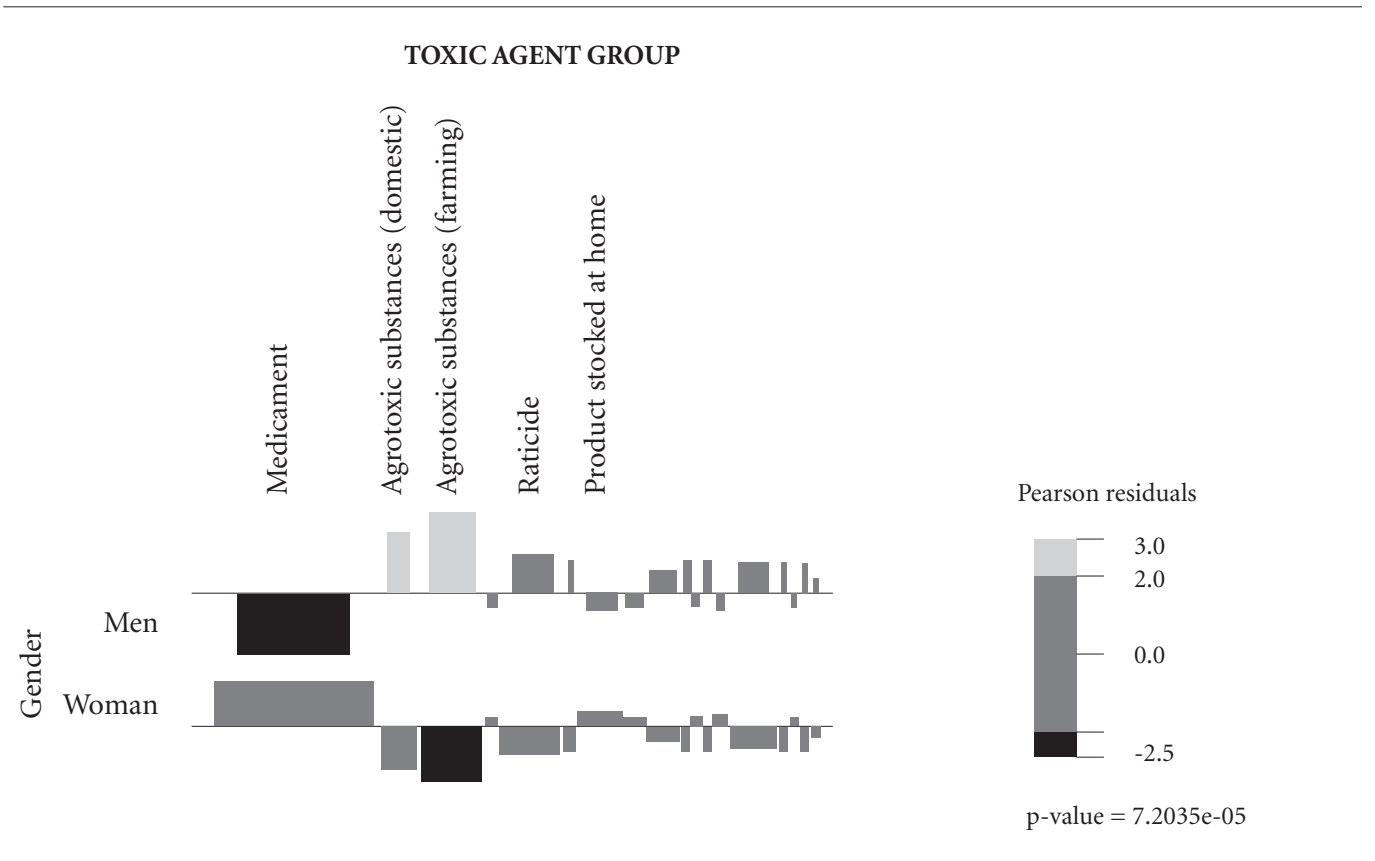

Chart 1. Relation of between Group varieties of toxic agent and Gender, according to suicide attempt cases assisted and notified by Ceatox-CG, Paraiba, Brazil, from 2010-2013 ( $\mathrm{n}=446)$.

The pesticides and household cleaning products represented, as solely applied toxic agents, counted for $64(14.3 \%)$ and $22(4.9 \%)$ of the occurrences, respectively. The pesticide inhibitor of cholinesterase, traded illegally as raticide ("chumbinho") was most frequently used $(13.5 \%)$ as single toxic substance. Application of agrotoxic substances (domestic or farming) was more common to the male gender compared to females. In the group of household cleaning substances most remarkable representative was sodium hypoclorite agent, with active clorum content between $2.0 \%$ and $2.5 \% \mathrm{p} / \mathrm{p}(3.4 \%)$ as the most common toxic substance.

The thematic map, based in Kernel's analysis, which built chromatic gradients around the suicide attempts, indicated the spatial distribution of cases as hot spots (Figure 1). The areas with highest risk were concentrated in the northeast of the map, reaching the extremes and the central region of the county. Around the hot spots, regions of lower density were visible. Populations inside the hot spots presented a higher risk of $38 \%$ (Relative Risk $=1.38$; IC $=95 \%$, p $=0.0029)$ to commit suicide when compared to populations residing outside of these hot spots. All together, it was estimated that the high- risk spatial area concentrated on average 165 suicide attempts per 100,000 inhabitants.

According to the LCI map shown above (Figure 2), neighbourhoods with better life conditions (in white) formed an agglomeration in the central region. The neighbourhoods adjacent to the city center presented intermediate conditions (in yellow). The worst index (brown and green), were visualized in the extreme east and north. Close neighbourhoods presented disparate life conditions. The average level's of incidence of suicide attempts in the life condition strata indicating higher incidence, were concentrated in the neighbourhoods with lower or intermediate LCI, An exception was the city center, that had a high incidence and a high LCI. Rate differences between high and intermediate life condition strata were notable. Neighbourhoods with lower LCI had an increase rate $(34.2 \%)$ of suicide attempts compared to the rate of suicide attempts in regions with most elevated conditions.

\section{Discussion}

The Toxic-supervision program in Spain identified for suicide attempts, an incidence rate of 


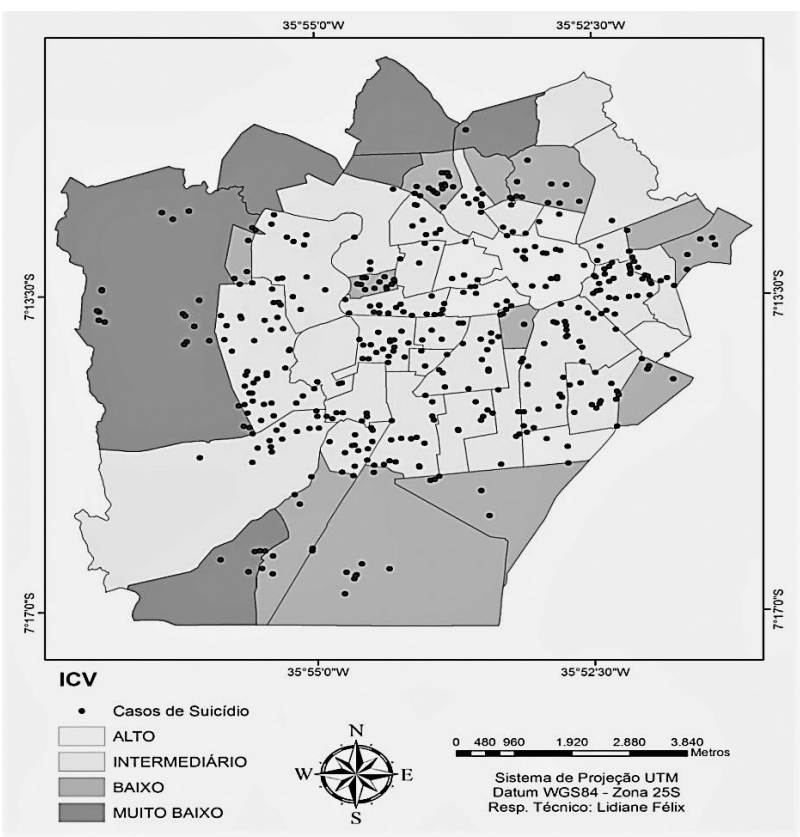

Figure 1. Estimation of density of suicide attempts by Kernel method in the urban area of Campina Grande-PB county, according to the cases assisted and notified by Ceatox-CG, Paraiba, Brazil, from 2010 to 2013 ( $\mathrm{n}=446$ ).

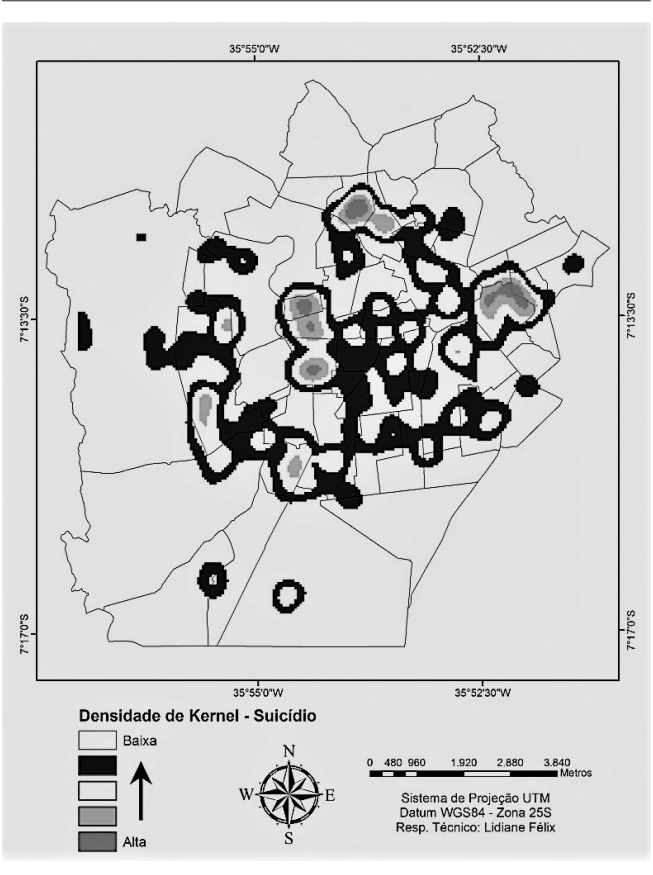

Figure 2. Distribution of spots in the urban area in the county of Campina Grande-PB, neighbourhoods, according to LCI, related to cases assisted and notified by Ceatox-CG, Paraiba, Brazil, from 2010 to 2013 $(\mathrm{n}=446)$.
$1.75 \%$ for patients admitted in emergency due to the abuse of drugs, alcohol, and medicaments, that are mainly benzodiazepines. Related to the circumstances, the suicide attempts got the second place in the circumstances ${ }^{19}$.

With 447 occurrences per 100,000 inhabitants the incidence rate of suicide attempts in Sri Lanka from 2008 to 2010 is considered to be highly elevated ${ }^{20}$. In the USA, from 2000 to 2008 , the estimated rate of self-poisoning varied, increasing from 55.8 to 67.9 occurrences per 100.000 inhabitants ${ }^{21}$. Italy had a rate of 42.7 occurrences per 100,000 inhabitants in each year during the same time $\operatorname{span}^{22}$.

In Brazil, between 2010 and 2015 all together 448,499 cases of intoxication based on chemicals like medicaments, abuse of drug, pesticides, and domestic cleaning products were registered. Of those, $33.2 \%$ were associated to suicide attempts. National- wide, the incidence for the same period was 13.3 out of each 100,000 inhabitants ${ }^{15}$. In Campina Grande County, from 2010 to 2013, the incidence rate was 120 cases per 100,000 inhabitants. This value was superior compared to those ones obtained from Spanish ${ }^{19}$, Italy ${ }^{22}$ and American ${ }^{21}$ studies and lower than in Sri Lanka ${ }^{20}$. Present results revealed a predominance of sui- 
cide attempts by the female gender and younge women. This is in agreement with several previous studies about suicide attempts from different countries $^{13,23-26}$. Furthermore present results indicated that rates of self-poisoning were increased in the group of elderly men. This may be due to an association between increased suicide risk and severe illnesses of elderly people, mainly of the male gender ${ }^{27}$. Other studies pointed out that the proportion of suicide attempts and mortality rates due to suicide, were obviously increased for all age groups of men, compared to the female gender ${ }^{28,29}$.

In agreement with present results, a research performed in Greece, with 940 registered cases of suicide attempts, revealed that most of these attempts occurred due to oral ingestion of remedies $^{5}$. A suggested reason refers to the habit of individuals having house stocks of remedies, which may provide access to suicide or suicide attempts ${ }^{26}$. Men frequently comined remedies with alcoholic beverages ${ }^{24,25,28,29}$ and women set up more than one kind of remedies ${ }^{25}$, strengthening our own study.

The remedies represented by psychotropic benzodiazepines predominated in the suicide attempts $^{10,28,30,31}$. Remedies of this class were predominantly Diazepam and Clonazepam ${ }^{23,30}$. The decrease of tension subjective to induction of quietness, are two important parameters to justify the popularity of these remedies, mainly in our restless way of life, in which population is inserted nowadays ${ }^{32}$. It was estimated that $11.67 \%$ of population that applies these remedies has started their usage by indication from family members or friends and that only $40.0 \%$ of applications had been prescribed by a psychiatrist ${ }^{32}$. Because of it's cheap and widely availability, Diazepam is frequently prescribed by Psychiatrists to treat chronic ways of anxiety ${ }^{33,34}$.

In the present study the use of antichlonesterasic pesticides (popularly "chumbinho") for suicide attempts was higher, when compared to other types of pesticides ${ }^{26,35,36}$. The organophosphates, including carbamate and herbicides are common agents used in rural district ${ }^{20,37}$ and, therefore, were less frequent in the present study of suicide attempts in a predominantly urban region. On one hand, usage of household cleaning substances for suicide attempts, represented by sodium hypochlorite with active chlorine content between $2.0 \%$ e $2.5 \% \mathrm{p} / \mathrm{p}$, was more common among individuals less than 20 years old. On the other hand, a previous pediatric study has shown that washing powder and detergents, that are products highly stocked at home ${ }^{38} \mathrm{can}$ be widely used because they are easily to find.

Cartographic identification of spatial agglomerates using ArcGIS 10, was performed in a previous spatial epidemiologic study from Kentucky, USA: Authors have found evidence for hot spots of attempts of suicide and suicides by several methods in all counties of Kentucky, as well as evidences of the existence of a cluster (agglomerate) of high risk of suicide from intoxication in the western region of the state ${ }^{39}$. The work by Saman et al..$^{39}$ revealed high levels of suicide inside spatial clusters (lower risk in outside areas), as well as the existence of a secondary cluster, where cases have been more susceptible to intoxication than outside this aggregation. Similar, a higher risk has been found in our analysis, in which we had the increase of risk and the incidence of "hotter" places (165 occurrences per 100,000 inhabitants). Identification of hot spots in the present study, by the Kernel method, provided evidence of risk areas, revealing that suicide does not take place at random in all regions and that the features of occurrence in the agglomerations tended to be different. The junction of Kernel's map and the LCI theme map allowed to infer that incidence distribution was featured by concentration of higher rates in neighbourhood of central areas and in the west of the county of Campina Grande. These neighbourhoods are known as being populous and having a high demographic density16. The bad strata neighbourhoods showed an increase of $34.2 \%$ of suicide attempts, when compared to higher income regions. However, when we observed some neighbourhoods singly, we could see that some of them with high LCI presented also high incidence and were considered determinant to lack of occurrence of higher gradient. The heterogeneity of these foundings may be explained by sub-notification of occurrences ${ }^{14}$, since in certain areas, especially in the most central ones, people have a better access to private hospitals, located near the town center. Another explanation would be environmental influence and relations with relatives, as experiences susceptible to contribute substantially to the etiology of suicide attempts of patients with psychiatric disorders ${ }^{7,36}$.

Comparable to previous studies ${ }^{40}$, present results showed that distribution standard of LCI has followed the model of social inequality, mainly in big urban centers, which are featured by outskirts having basic urban infra- structure with lower income residents and characterized by bad health care conditions. Finally, identification 
of homogenous areas and neighbourhoods with similar features may facilitate strategy choices and specific interventions adapted for needs of residents ${ }^{41}$. Furthermore, resources could be prioritized in high- risk areas in order to reduce suicide attempt rate ${ }^{39,42}$, having as an example the most central regions of the community.

The major limitation of this study was the difficulty to find a professional of geo-processing, capable to work with a geographic information system for public health care. Another difficulty had to do with localization of coordinate points of the digital loop, referring to the rural zone of the counties, the "cariri"- area of Paraiba, making it impossible to work with these localities, due to the low cartographic quality. In the study design, there was the aggregated effect, long ago called ecological fallacy, but without making any harm to the quality of analyzed data ${ }^{43}$.

\section{Final considerations}

The Health Care Ministry manual, addressed to professionals of Mental Health Care teams, pointed out some risk factors to suicide, among them, socio-demographic factors as gender, age, and economic status. In the present study, we highlighted that incidence of suicide attempts had been diversified, according to relation between gender and age variables, as well as between gender and agents used. The county of Campina Grande, Paraiba, presented higher incidence of suicide attempts for both genders, when compared to data of Brazilian and American statistic. Through Kernel's graphic analysis it was possible to remark higher incidence by formation of hot spots located mainly in the central and north- eastern regions of the county. Through LCI, we presumed better and worse life condition areas, thus revealing that there was an elevated risk of suicide attempts in regions with decreased life conditions. Although Brazil has advanced when ordinance number 1,876 was released in August 14th, 2006, there is still a lot to do in the prevention field. This ordinance established national regulations for implementation of suicide prevention in all federal units, respecting the competences of the three governmental levels, and orientated a further national plan to prevent suicide ${ }^{44}$.

Having this background in mind, the present study provides important information for health care professionals about cases of suicide attempts which may contribute to promote prevention measures of this harm in the population, according to the guidelines and strategies established by Ordinance No 1.876/GM on August 14th, 2006, considering the deals for health care in its three dimensions. As long as the theme involves a complex process influenced by socio-economic and geographic aspects, there is a need for a larger control from managers and professionals of health care services on the implementation of measures leading to supply the drawing of strategies to prescribe, dispense, and use of toxic substances.

This way, taking the seriousness of suicide attempt into consideration as illness socially produced, the number of toxic agents used to such aim, and the facility to obtain them, as well as identified high risk areas, emphasize that this spatial analysis method can also have a wide application range for research and practice of mental health care programs. Thus, it's extremely important to carry on the research with geoprocessing in order to deepen the knowledge about location influence, over areas with an increased incidence. Furthermore, in future studies we may be able to answer to a central question which has not been clarified in this work: Why presented the central area of the community an increased incidence even if it has a high life standard? 


\section{Collaborations}

TSO Almeida participated in the design of the project, outline, data analysis and interpretation, writing of the paper. SML Fook participated in the design of the project and its critical review. SR Mariz participated in the critical review of the paper.ELS Camêlo participated in the statistical analysis of the data. LCG Gomes was responsible for geoprocessing of the data.

\section{References}

1. Vidal CEL, Gontijo ECDM, Lima LA. Tentativas de suicídio: fatores prognósticos e estimativa do excesso de mortalidade. Cad. Saude Publica 2013; 29(1):175-187.

2. Demirçin S. Suicide of elderly persons: Towards a framework for prevention. Geriatrics \& Gerontology International 2011; 11(1):107-113.

3. Hawton K, Van Heeringen K. Suicide. Lancet 2009; 373(9672):1372-1381

4. Nock MK, Borges G, Bromet EJ, Alonso J, Angermeyer M, Beautrais A, Bruffaerts R, Chiu WT, de Girolamo G, Gluzman S, de Graaf R, Gureje O, Haro JM, Huang Y, Karam E, Kessler RC, Lepine JP, Levinson D, Medina-Mora ME, Ono Y, Posada-Villa J, Williams D. Cross-national prevalence and risk factors for suicidal ideation, plans and attempts. Br J Psychiatry 2008; 192(2); 98-105.

5. Fountoulakis KN, Savopoulos C, Apostolopoulou M, Dampali R, Zaggelidou E, Karlafti E, Fountoukidis I, Kountis P, Limenopoulos V, Plomaritis E, Theodorakis P, Hatzitolios AI. Rate of suicide and suicide attempts and their relationship to unemployment in Thessaloniki Greece (2000-2012). J Affect Disord 2015; 174:131136.

6. Cheung K, Aarts N, Noordam R, van Blijderveen JC, Sturkenboom MC, Ruiter R, Ruiter R, Visser LE, Stricker BH. Antidepressant use and the risk of suicide: A population-based cohort study. J Affect Disord 2015; 174:479-484.

7. Levine SZ, Goldberg Y, Yoffe R, Pugachova I, Reichenberg A. Suicide attempts in a national population of twins concordant for psychoses. Eur Neuropsychopharmacol 2014; 24(8):1203-1209.

8. Reutfors J, Bahmanyar S, Jönsson EG, Brandt L, Bodén R, Ekbom A, Osby U. Medication and suicide risk in schizophrenia: A nested case-control study. Schizophr Res 2013; 150(2-3):416-420.

9. Mello-Santos C, Bertolote JM, Wang YP. Epidemiology of suicide in Brazil (1980 - 2000): characterization of age and gender rates of suicide. Rev Bras Psiquiatr 2005; 27(2):131-134.

10. Muheim F, Martin E, Pascal B, Stephanie C, Gabriela S, Merle K, Anita RR. Suicide attempts in the county of Basel: results from the WHO/EURO Multicentre Study on Suicidal Behaviour. Swiss Med Wkly, Basel 2013; 143: w13759.

11. Liotta M, Mento C, Settineri S. Seriousness and lethality of attempted suicide: A systematic review. Aggression and Violent Behavior 2015; 21:97-109.

12. Mowry JB, Spyker DA, Broks DE, McMillan N, Schauben JL. 2014 Annual Report of the American Association of Poison Control Centers ' National Poison Data System (NPDS):32st Annual Report. Clinical Toxicology 2015; 53(10):962-1147.

13. Fiocruz/CICT/Sinitox. Fundação Oswaldo Cruz/Science and Technology Research Centre/ Toxic-Pharmacologic Information National System. Annual Statistic of Poisoning and Intoxication Occurrences. Brazil. [cited april $\left.25^{\text {th }}, 2014\right]$. Available from: http://www.fiocruz.br/ sinitox/cgi/cgilua.exe/sys/start.htm?sid=8 
14. Santos AS, Legay LF, Lovisi GM. Toxic Substances and Suicide attempts: considerations about restrict accesses and measures. Cad. Saúde Colet. 2013; 21(1):53-61.

15. The National System of Aggravations and Notification (Sinan). Intoxicação Exogéna. [cited May $4^{\text {th }}, 2016$ ]. Available from: http://www2.datasus.gov.br/DATASUS/index.php?area $=0203 \&$ id $=29878153$

16. Brazilian Institute of Geography and Statistics (IBGE), 2010. Available census 2010. [cited april 22th 2014 ]. Available from: http://www.censo2010.ibge.gov.br/sinopseporsetores/?nivel=st

17. Paim JS, Silva LMV, Costa MCN, Prata PR, Lessa I. Inequality of the health care situation in the county of Salvador and relations with life conditions. Rev Medical and Biological Sciences 2003; 2(1):30-39

18. Ribeiro LCC. Life conditions and spatial distribution of tuberculosis in Campina Grande county - PB [dissertation]. Universidade Estadual da Paraíba: Campina Grande; 2012.

19. Muñoz R, Borobia AM, Quintana M, Martínez A, Ramírez E, Muñoz M, Frías J, Carcas AJ. Outcomes and Costs of Poisoned Patients Admitted to an Adult Emergency Department of a Spanish Tertiary Hospital: Evaluation through a Toxicovigilance Program. PLOS ONE 2016; 11(4):e0152876.

20. Senarathna L, Jayamanna SF, Kelly PJ, Buckley NA, Dibley MJ, Dawson AH. Changing epidemiologic patterns of deliberate self poisoning in a rural district of Sri Lanka. BMC Public Health 2012; 12:593.

21. Bernardes SS, Turini CA, Matsuo T. Profile of suicide attempts using intentional overdose with medicines, treated by a poison control center in Paraná State, Brazil. Cad Saude Publica 2010; 26(7):1366-1372.

22. Poma SZ, Toniolo E, Grossi A, Pizzo R, Cocchio S, Baldo V. Epidemiology of suicide attempts in a psychiatric setting in Northern Italy. Journal of Psychopathology 2013; 19:119-125.

23. Bertasso-Borges MS, Rigetto JG, Furini AAC, Gonçalves RR. Eventos toxicológicos relacionados a medicamentos registrados no Ceatox de São José do Rio Preto, no ano de 2008. Arq Ciênc Saúde. 2010; 17(1):35-41.

24. Kaplan MS, Huguet N, McFarland BH, Caetano R, Conner KR, Giesbrecht N, Nolte KB. Use of alcohol before suicide in the United States. Ann Epidemiol 2014; 24(8):588-592.

25. Prieto D, Tavares M. Fatores de risco para suicídio e tentativa de suicídio: incidência, eventos estressores e transtornos mentais. J Bras Psiquiatr 2005; 54(2):146154.

26. Santos SA, Legay LF, Lovisi GM, Santso GFC, Lima LA. Suicídios e tentativas de suicídios por intoxicação exógena no Rio de Janeiro: análise dos dados dos sistemas oficiais de informação em saúde, 2006-2008. Rev Bras Epidemiol 2013; 16(2):376-387.

27. Minayo MCS, Cavalcante FG. Suicídio entre pessoas idosas: revisão da literatura. Rev Saude Publica 2010; 44(4):750-757.

28. Darke S, Duflou J, Torok M. Drugs and violent death: comparative toxicology of homicide and non-substance toxicity suicide victims. Addiction 2009; 104(6):1000-1005.
29. Jones AW, Holmgren A, Ahlner J. Toxicology findings in suicides: Concentrations of ethanol and other drugs in femoral blood in victims of hanging and poisoning in relation to age and gender of the deceased. Forensic and legal medicine. 2013; 20(7):842-847.

30. Gandolfi E, Andrade MGG. Eventos toxicológicos relacionados a medicamentos no Estado de São Paulo. Rev Saude Publica 2006; 40(6):1056-1064.

31. Rios DP, Bastos FM, Cunha LC, Valadares MC. Tentativa de Suicídio com o uso de medicamentos registrados pelo CIT-GO nos anos de 2003 e 2004. Revista Eletrônica de Farmácia. 2005; 2(1):6-14.

32. konopka A, Pełka-Wysiecka J, Grzywacz A, Samochowiec J. Psychosocial characteristics of benzodiazepine addicts compared to not addicted benzodiazepine users. Prog neuropsychopharmacol biol psychiatr 2013; 40:229-235.

33. Jindal A, Mahesh R, Kumar B. Anxiolytic-like effect of linezolid in experimental mouse models of anxiety. Prog. Neuropsychopharmacol biol psychiatr. 2013; 40:47-53.

34. Magalhães PVS. Uma reavaliação do Diazepam intramuscular para emergências psiquiátricas. Rev Psiquiatr Clin 2009; 36(3):122-122. (Carta).

35. Martins EHC, Farias AJC, Gonçalves CSM, Bárbara EBS, Filho EPC, Braga AMCB. Intoxicações por Aldicarb no Estado da Bahia, Brasil. Rev Bahiana Saúde Públic. 2005; 29(1):77-88.

36. Werneck GL, Hasselmann MH, Phebo LB, Vieira DE, Gomes VLO. Tentativas de suicídio em um hospital geral no Rio de Janeiro, Brasil. Cad Saude Publica 2006; 22(10):2201-2206

37. Andrew HD, Eddleston M, Senarathna L, Mohamed F, Gawarammana I, Bowe SJ, Manuweera G, Buckley NA. Acute Human Lethal Toxicity of Agricultural Pesticides: A Prospective Cohort Study. PLoS Medicine 2010; 7(10):1-10.

38. Silva AAR, Passos RS, Simeoni LA, Neves FA, Carvalho E. Use of sanitizing products: safety practices and risk situation. J Pediatr 2013; 90(2):149-154.

39. Saman DM, Walsh S, Borówko A, Odoi A. Does place of residence affect risk of suicide? a spatial epidemiologic investigation in Kentucky from 1999 to 2008. BMC Public Health 2012; 12:108.

40. Vendramini SHF. O programa de controle da tuberculose em São José do Rio Preto-SP, 1985-2004: do contexto epidemiológico à dimensão social [tese]. Ribeirão Preto: Escola de Enfermagem da USP; 2005.

41. Chiesa AM, Westpha MF, Kashiwagi NM. Geoprocessamento e a promoção da saúde: desigualdades sociais e ambientais em São Paulo. Rev Saude Publica 2002; 36(5):559-567.

42. Holowaty EJ, Norwood TA, Wanigaratne S, Abellan JJ, Beale L. Feasibility and utility of mapping disease risk at the neighbourhood level within a Canadian public health unit: an ecological study. Int $J$ Health Geogr 2010; 9(21):1-14.

43. Medronho RA, Bloch KV. Epidemiologia. 2a ed. Rio de Janeiro: Atheneu; 2008. 
44. Brasil. Ministério da Saúde (MS). Portaria No 1.876, de 14 de agosto de 2006. Institui Diretrizes Nacionais para Prevenção do Suicídio, a ser implantadas em todas as unidades federadas, respeitadas as competências das três esferas de gestão. Diário Oficial da União 2016; 15 ago.

Artigo apresentado em 06/10/2015

Aprovado em 22/06/2016

Versão final apresentada em 24/06/2016 